\title{
Protreptikos - the Exhortation for Scientific Tourism ${ }^{1}$
}

\author{
Jerzy Kosiewicz
}

Josef Pilsudski University of Physical Education in Warsaw, Poland

KEYWORDS

\begin{abstract}
The presented paper focuses primarily on the tourism activities of teaching staff at universities and other research institutions. This applies in particular to travel during which the principal purpose is, inter alia, various exploratory internships, conferences, trips as a guest professor or a visiting professor under the auspices of the Erasmus and Erasmus Mundus programs. These peregrinations require extra effort, not only with regards to teaching and research duties, but also present opportunities to confront, test and evaluate one's own research results and outlook with new listeners in new locations in different environments. This travel especially applies to the foreign environment, a situation that presents high degrees of professional, scientific and linguistic challenges, resulting in increased contributions and activity to the specific field of science. Regardless of the workload and the difficulties of the discussed travel, such travel can also bring about much personal satisfaction: a) due to a sense of a well done job as a result of meeting expectations of the employer and the host placed on the 'messenger of science' and b) due to the pleasure associated with those tourist experiences having autotelic and pragmatic (instrumental) overtones.

protrepticos, professional tourism, scientific tourism, philosophical tourism, protreptical tourism
\end{abstract}

\section{Scientific tourism as a duty and pleasure}

Scientific tourism is travel associated with a particular professional activity, i.e. the practice of science. In that general meaning, scientific tourism does not differ from other forms of tourism associated with professional activities - for example, those related to politics, business (business tourism), numerous tourist organizations (for example, travel agents), or various forms of culture. In such cases, including scientific tourism, the main objective or goal in itself, the autotelic aim of the professional activity is not the traveling or tourism itself. Activities also present in scientific tourism, such as traveling, peregrinations, hikes, pilgrimages, and traversing longer or shorter distances, only play a support role in complying with the overarching objectives of a particular profession. They facilitate the realization of objectives that differentiate and create the essence of a particular profession, whether it is science, or any other specific activities such as artistic, political, military, sport, or economic.

Taking this into consideration we may conclude that travel in the indicated situation has a merely inferior nature - both substantively and axiologically - in relation to the essence of a particular

\footnotetext{
${ }^{1}$ This thesis was prepared within the framework of the statutory research - 152 on 'Sport in the process of social and cultural transformation in Central Europe' financed by the Ministry of Science and Higher Education.
} 
profession. As such, it is (and should be) treated instrumentally, i.e. as a means to achieve the profession's overarching goal or purpose.In the aforementioned cases, we are dealing with professional tourism. However, to avoid confusion, it should be noted that professional tourism might occur at least in two basic forms:

1. Tourism treated sensu stricte as a profession, meaning that the tourism itself becomes an occupation. This applies to, for example:

a) Sherpas in Nepal, who for a fee accompany expeditions supporting them on their way to selected Himalayan peaks,

b) travel journalists preparing news reports regarding their expeditions for radio, film, television in the form of interviews, articles, feature-length stories and novels,

c) Polish residents serving Polish tourists in foreign holiday resorts,

d) guides for national and international tourists.

2. Tourism as a component or manifestation of some different, not necessary tourist or recreation-oriented profession. In these cases, travel creates and expands the possibility of the completion of plans, tasks, programs, and projects that determine the activity undertaken in such professions. The indicated tourism may serve as a way to vary and enrich activities related to the occupation by establishing new contacts and than setting new institutional and organizational as well as practical and theoretical objectives.

In the case of the second type of professional travel - the main cognitive axis of the presented text - tourism can play an important and instrumental role. It can facilitate the development and improvement of a specific profession. It can also play a complementary and at the same time strengthening factor in grounding someone's research presence in a particular scientific community. This applies to both domestic ${ }^{2}$ and foreign travel. In particular, the latter are important for professional development, due to the extent to which research areas and organizational and creative opportunities arise from that type of travel. This also applies to the pure tourist experience, especially those triggered by new and distant places. Oftentimes, a travel experience's uniqueness, originality and intensity may significantly overshadow, or even dominate, the professional experience. However, only the utilitarian and creative achievements associated with the travel and activities in certain areas will serve as the main basis for clearing the expenses of the trip by the financing institution, which is interested mostly in the formal and substantial development of the appointed area. It is worth noting that, for the institution financing the travel, experiences that accompany the realization of scientific and educational purposes do not have even minor importance. What matters is mainly the presence of a certain community and (in short) the exchange of experiences and activities related to the scientific area.

These activities include:

a) networking with regards to conducted research,

\footnotetext{
${ }^{2}$ Andrzej Piskozub describes in a persuasive and funny way how, despite a lack of adequate financial resources, he embraced on his own assumptions of scientific tourism during the time of Polish People's Republic: "The peculiarity of the upside down economic system of communist Poland was that, on the one hand the meager salaries of teachers made it virtually impossible to have a 'tourist expenses account' [It was well described by a Canadian journalist who after visiting Poland in the era of Gomulka wrote: 'In this country people pretend to work for 30 days, and at the last day of the month, the government pretends to pay them for it.'] Yet on the other hand, a university teacher, as long as he wanted, could pursue within his own country quite a substantial tourism program, without spending anything on it (or almost anything) from his own pocket. It was enough to combine an individual travel plan with a business trip funded by a university or with an invitation from different institutions and associations to participate in a conference or lecture. All expenses were covered by the hosting institution and thus the entire self-tourist program accompanying the business trip to interesting tourist destinations was in effect sponsored by the state budget. Those who did not see these possibilities, or those who were not interested in using them, can be described with Wyspiański's words: they do not want to want. However, I wanted, and during a quarter of the century, with the book Guide to Poland in my hand, I wandered through the entire territory of this country"(A. Piskozub, Similarities and differences between the business tourism and scientific tourism; http://berda.nazwa.pl/htdocs/ymagomundi.eu/PDF/turystyka.pdf).
} 
b) organizing new projects and research teams,

c) attending doctoral, postdoctoral and professorial research internships, as well as other internships and training,

d) cooperating in the establishment and development of scientific societies at national and international levels,

e) participating in organizational committees and scientific committees at national, continental and global conferences,

f) presenting papers in the form of oral or visual presentation, leading topic sections and thematic sessions,

g) creating editorial boards for national and international journals,

h) coordinating editorial work connected with the publication of scientific monographs including books of one or collected domestic and foreign authors,

i) attending research and teaching projects, for example, in Erasmus or Erasmus Mundus programs as a visiting professor or guest professor, giving a lecture based mainly on the results of one's own research and team research, not to be found in already disseminated textbooks.

The aforementioned forms of scholarly and scientific-educational activities (for instance, in the Erasmus program) create particularly meaningful opportunities to represent the university or any other research, scientific or educational institution. In this paper it applies only to teachers at academic and research institutions. Scientific travel provides opportunities for direct, live contact with others interested in explored areas of science. It also allows one to maintain and strengthen formal, institutional and substantive ties.

These types of relationships are irreplaceable.

\section{Traveling as main objective and research tool}

Scientific tourism can also be seen from two different points of view, namely:

1. On the one hand, it may involve research directly related to travel. An example might be traveling to the Africa in order to conduct studies on the trip's destination. This type of travel is a form of a professional tourism, because the participants are professional explorers. Traveling in this case has an autotelic overtone in the sense that it serves as a part of the main goal. Traveling is a part of the trip's aim, the only way to reach the content of the expedition, to get to the essence of the studies, as well as to fulfill the trip's objectives. However, traveling is not a subject of studies in this case. Analyzed are only the results of reaching the destination (Jafari, El-Rouby and Wahab 1992, Ilyina, Mieczkowski 1992, Dupain, Belani, Likondo, Nzita and Omasombo 2006, West 2008, Bloom 2010, Bertella 2011). The subjects of studies, therefore, are the primary goals. Traversing the continent, country, region, ocean, sea or other water body provides the necessary research material. Travel is inherently linked to the merits of the process and to the content of the conducted exploration.

2. On the other hand, travel might instrumentally facilitate the presentation of results of previous studies. It may not be substantially related to the exploration itself. In both cases, the travel allows for scientific activity. In the first case, travel is an inherent element of the essence of the study, while in the second case, travel is external to the essence of the study, as the subject of the research has nothing to do with the empirical methodology of the natural scientific exploration and necessary for that purposes travels.

At this moment, it is worth noting the difference between the epistemological and epistemic functions within the context of cognitively oriented tourism. It can be easily seen using the example of space travel; such travel has dual cognitive characteristics:

1. The first aspect is strictly exploratory and epistemological. These travels develop scientific knowledge concerning, inter alia, the construction of space and the universe. Study is carried 
out by professionals well prepared for these kinds of activities, those astronauts selected and trained for this work.

2. The second aspect is epistemic (episteme), so associated with everyday knowledge. Although in this case cognition has an individual nature and refers to the individual experience of space, it's not necessary tied to scientific research of any kind. This type of travel, resulting in a highly specific and unique travel experience, is the main objective itself. The travelers are neither prepared for conducting studies nor are they trained professionals. The nature of such a journey is not related to highly sophisticated and extremely expensive studies, and as such, does not have a professional nature. The offer of such travel became possible as a result of more and more popular services offering extremely expensive short-term trips into space.

\section{Science and tourism?}

However, science is not the main thematic axis in this article. The focus is on the second part of the expression: 'scientific tourism,' i.e. tourism with special attention brought to the travel experience. Regardless of the travel experience content, meaning, importance or significance, such travel is always, in every discussed case, propelled and caused by the cognitive and emotional needs of conducting some scientific or scientific and didactic activity.

Referring to the subtitle of the this paper, it can be concluded that scientific tourism is primarily a professional responsibility and commitment in a twofold sense:

a) an obligation in the sense that it represents a specialized form of professional activity, required for maximum professional development and performance,

b) mandatory in another meaning, as it is a fundamental and indispensable obligation for every person who deals with science. In such cases, there is a need for the constant exchange of views as well as cooperation with peers in one's field. Electronic communication in this respect is very useful but no substitute for direct participation in scientific travel.

These trips always require an extra effort, not only with regards to teaching and research duties, but it is also an opportunity to confront, test and evaluate one's own results and research outlooks with new listeners in a new location in a different environment. This especially applies to a foreign environment, a situation presenting high professional, scientific and linguistic challenges, resulting in increased contributions and activity in the field.

Regardless of the workload and the difficulties of the discussed travel, such travel can also bring much personal satisfaction:

a) due to a sense of well done job, resulting from meeting the expectations of the employer and the host placed on the 'messenger of science',

b) because of the pleasure associated with the tourist's experiences having autotelic and pragmatic (instrumental) overtones.

\section{Organized and unorganized forms of scientific tourism}

Discussed in this text is a form of scientific tourism that is predominantly organized; as a matter of fact, it is organized to a high degree. This applies primarily to:

a) the meeting place - in the form of convention centers or hosting universities typically encountered in various cities,

b) the location of lectures and place of residence (hotel),

c) the board provided by the host,

d) routinely organized forms of plane and railway transportation, associated with reaching the destination of scientific peregrinations,

e) the standard tourist offers in the form of sightseeing tours, walking tours, visits to museums and other cultural places, etc. 
This highly organized part of the trip is connected mainly with the essential aspect of scientific tourism, that is, on science. It results from the fact that in the case of travel for university teachers, researchers, scholars (student travel is not a subject under consideration), there is usually a specialized department of university or research institution dedicated to organizing scientific trips: for instance, the Polish Academy of Sciences and its equivalent in other countries.

When you examine not just the institutional aspects, but instead consider the participants' strictly subjective and individual experiences, then it may be that these aspects of a scientific trip are particularly important, and sometimes have even more substantial significance for the research project than the epistemological results. It might indeed occur that the emotional, aesthetic, hedonistic, ludic, cathartic or escapist experiences during the trip result in good rest and relaxation. In contrast with the everyday involvements and routines of professional conduct, the value such travel might bring can include the participants' mental and physical health.

Exceptions to this entrenched framework of organized tourism, as imposed by the administrator and a host of scientific and educational projects, might also occur in the form of attempts by participants to adapt the travel to their individual needs. It happens that academics and researchers organize trips on their own, adapting the course of travel to their own preferences. They might refrain from arranged flights and instead choose a car trip with their family or friends: for example, from Warsaw to Jyvaskila, visiting along the way - albeit briefly but intensively - Belarus, Lithuania, Latvia and Estonia. They can also organize their own individual or sightseeing excursions in line with their interests and needs, independent from the proposals or suggestions offered by the organizers of the scientific and scientific-educational events.

However, it is worth noting that beside experiences that occur during independently organized ventures, exciting and unforgettable moments can also happen during a trip organized in a standard way.

Four of my own trips to the UK will serve as example and proof of the statement made above:

1. The first example concerns my trip to the University of Gloucestershire in England for a conference organized by the International Association for the Philosophy of Sport in 2002. When I got off the train in Gloucester, I took a taxi to the university. To my surprise the driver took me to another city - to Cheltenham, where the University of Gloucestershire is located.

2. Two years later, I went to the University of Stirling for a working meeting on an international research project funded by the European Committee. In Birmingham, I boarded a train. At the train station in Stirling - a city with specific, impressive, traditional architecture - I asked cautiously, how far is it to the university. I was told that the University of Stirling was elsewhere - in a town called Bridge on Allan. I got there via the next train.

3. In 2004 I was also invited to Durham as keynote speaker for the conference of the British Philosophy of Sport Association. I informed the organizers of my arrival date, as I was supposed to get a taxi ride to the hotel. In several e-mails my hosts asked me to change the ticket so I could land at Newcastle Airport. I refused because I thought the issue was not important. But it turned out that the airport in Durham is over 40 miles away from the center of the city, while the Newcastle Airport is just 15 miles away.

4. While traveling to the University of Stirling for the second time (in 2007) as a visiting professor, I landed in Glasgow. It just as easily could have been Birmingham, because the university is located midway between the two cities. After the lectures, Prof. Grant Jarvie (vice-provost) ordered a taxi for me to the airport (about 60 miles from the university). Surprisingly, the taxi drove to Birmingham instead of Glasgow. Grant probably thought that either airport would be good for me, since I had a ticket to Warsaw.

My enchantment for Great Britain probably will never pass. 


\section{Scientific tourism in the context of axiology and heroism}

In reflecting on the concept of tourism, an axionormative, judgmental opinion justifying one form of tourism over another might be encountered. However, I would like to emphasize at the outset of further considerations that a superiority of any selected forms of the tourism over other cannot be shown - regardless of the context of the justification - whether we consider the context of axiology, or the general and specific methodology.

In the normative area regarding the realm of tourism and various forms of recreation or leisure activity, values and preferences are constantly evolving. Therefore, a categorical and definitive complex of assumptions, arguments and normative postulates regarding tourism, excluding variety of concepts and perspectives, shall not be formulated. There are no objective and universal categories, or one indisputable common denominator, on the basis of which a formally and substantially inarguable hierarchy can be created. The objective categories to create such classifications of the various forms of tourist activity - from the most important, most valuable, and most significant to the least desirable and recommended - cannot be found.

Imposed solutions saturated with dogmatic values often receive no acceptance, as no one has to cultivate tourism in accordance with some dictated model. According to the foundation of democracy, people also have freedom of choice in that matter. They usually choose options which are relevant to their assumed goals, optimal axiological results, and means of achieving them - whatever their choice might seem to others, whether more or less controversial. There is no objective reason to depreciate the tourist who spends his time in the holiday resort, domestic or foreign, only at the pool or on the beach, while consuming the high-calorie diet full of rich food and alcohol, served in the all inclusive offer, if he chose to do so.

We can conclude here, referring to the axiology, that the roots of tourism-related behavior, choices and axiological postulates are underlined in relativism, which indicates that all values occurring in tourism are relative. However, it does not apply to pragmatic norms, regulations, and administrative rules formulated, for example by travel agencies, by universities and other research institutions related to scientific tourism. Also, relativism does not apply to broadly understood legal standards applicable in the place of residence, in transit countries, as well as in the tourist's country of destination.

Relativism in the field of tourism involves subjective and personal preferences. An individual has the right to meet his own needs, if it does not create a conflict with the aforementioned regulation of the pragmatic and non-axiological overtones. In this sense, it is an individual - if he wants, and feels so - who is ultimately the most important arbiter of the value of the tourism he prefers. This also applies to the ad hoc, spontaneously undertaken decisions that are defined - from the standpoint of axiology - as the values and dispositions with situational overtones. This applies to decisions made in the here-and-now, underlined by an instant, emotional choice. The choice is only affected by an individual who has succumbed to situational impulses with often surprising properties including, for example, social, historical, political, ideological, religious, ethnic, local, geographical and climate. The axiological judgment and related behavior based on variables of environmental interactions are defined, in light of axiology, as situationism.

Referring to situationism, decisions and their consequences with behavioral overtones can also be called axiotic, as they are undertaken regardless of axiological reflection; that is, regardless of any knowledge related to the theory, science or philosophy of values. Incidentally, each type of intellectual and behavioral disposition demonstrated by a tourist - not only those primed in situationism - will be axiotic, if it does not refer, more or less indirectly, to the assumptions of axiology as a branch of philosophy.

This does not mean that the decision mentioned above is wrong and the behavior inappropriate. In terms of normative choices of a non-rational or non-scientific nature, the key role may lie in socalled common sense. In the considered issue, it could be an essentially intuitive disposition to 
judgment, which cannot be justified in any discursive way, and which is influenced by previous personal experience and opinions of reliable people who are recognized - in the tourist's surroundings, whether near or far - for their experience in the matter in question. In order to describe undertaken decisions in this case, the category of ethical prudence can be used. This category can be derived from the concept of Christian prudence (Rosik 1986). This concept appeared as an equivalent of situationism, limited, however, by the principles of Catholic ethics. It does mean to unconditionally and absolutely follow Christian moral rigor, as this is not the only absolute and ultimate value, and cannot be treated as an ethical and behavioral goal. The main goal is the moral good, especially those ethical actions which include compassion, trust, tolerance, faith in reason, good intentions and a fair balance between the good and bad characteristics of certain choice which will not remain in conflict with the overall concept of Christian morality.

The category of ethical prudence I have proposed, also related to aspects of values in tourism, indicates that in a situation of choice, one will pursue the most meaningful, accurate, balanced and prudent (in a given situation) decision. The category also takes into consideration both the short- and long-term perspectives when assessing the usefulness and benefits of a decision's outcome for the individual as well as the micro- and macro-social dimensions. Nota bene, as both the concept of ethical prudence and usefulness are intuitive in nature, having slightly emotional and relativistic overtones. It is impossible to determine an unambiguous definition.

Although in axiological situationism, judgmental decisions are not subject to evaluation in terms of logical truth or falsity, the assumptions of William James' pragmatic theory of truth (James 1951) can be applied to these decisions. The theory indicates that the truth of the decision, including the scientific decision of both speculative (philosophical) and practical nature, depend on the potential benefit and utility, criteria which underlie the pragmatic theory of truth.

The basic assumptions of J. P. Sartre's axiology, ones that create the foundation of his ethics of heroism (Sartre 1985) can also be applied to the discussed issue. The choice of specific values will always raise doubts within people interested in its consequences. Doubts may concern relevance and accuracy, as there is no universal, objective and ultimate axiological model with which it may be possible to determine approximations of these values which occurred as a result of decisions. Therefore, every choice of certain values, including those undertaken or assumed dispositions in the area of tourist activity, will be marked with some stigma of heroism (in accordance with the ethics of heroism). One can never be sure that the chosen direction of action will be fully beneficial or negative. Nor will one ever get to know all the diverse and unpredictable consequences of choice which may appear soon or in the future.

The motive of heroism will appear in tourism in its double sense. On the one hand, it will be related to the unknown and unpredictable consequences of choosing one of many emerging options for the optimization of further travel. On the other hand, heroism in tourism involves not so much axiology as the practical consequences of planning that occurs with every choice of one traveling option over another. Every choice made by a tourist can lead to a heroic struggle with adversity, fighting for survival while traversing a vast desert, a mountain, the Arctic, or during transoceanic yachting. Therefore, in tourism, the axiological provenance of the heroism of choice is often closely associated with biological heroism, supernatural human effort and struggle to preserve the life or physical function in extreme situations.

\section{Religious values and scientific tourism}

Apart from ontology, which accepts the existence of ideal entities, it can be assumed that there are no objective values that exist independently from humans. With regard to tourism in general, and scientific tourism in particular, there are no objective values which will oblige a subject to fulfill them. This means that values are not given externally either by: 
a) a supernatural power with transcendent features of religious provenance,

b) entities with transcendental features of philosophical provenance, such as from philosophies which posit the existence of ideal entities as efficient causes, i.e. the Demiurge in Plato's philosophy, or First Cause, Prime Mover, or God's Mind in the views of Aristotle.

It is not possible to create such a context of justification that conclusively proves the possibility of universal values. On that basis, it can also be assumed that there is no universal form of tourism in general, or any values representing universal tourism, that can saturate any particular manifestation of tourism. Therefore, it is impossible to extract such a form of scientific tourism that is based on incontestable and necessary values. There are no fundamental, universal or objective standards related to traveling, nor are there axionormative rules of conduct for tourism. Diversified needs, the manner in which such needs are fulfilled, as well as manifold cultures and civilizations, make the existence of common, permanent and imperative rules rather implausible both on the pragmatic and the normative levels. Therefore, freedom of choice is in force - limited, of course, by individual and collaborative capabilities, as well as the situational conditions encountered on the tourist's path.

From the standpoint of axiology, epistemology, ontology and other possible independent branches of philosophy, there are no objective values - including those with religious overtones, which represent vital, uncontested, universal, or exception-free foundations for tourist activity. However, religious views - including these of the vertical source of inspiration - are an important cause of travel in general, and scientific tourism in particular. Despite the impact of often-severe social judgment, religiously motivated trips are testimony to the possibility of choice in line with individual needs.

Relativism in religiously conditioned tourism is testimony to relativity and freedom of choice in the sense that one's point of view when referring to faith is not imposed. Walking pilgrimages are performed by believers according to the needs of people in many religions and take place regardless of experience or historical and cultural conditions underlying the supporters of different points of view. Relative determinants refer to the environment of a specific believer and the social relationships that occur in this environment. Relations define religious determinants. Participation in religious associations, as well as in certain forms of worship, including pilgrimages, are in a genetic and primal sense voluntary activity, which means that there is no compulsion in terms of the generally applicable, imposed rule of law. Thus, there is freedom in terms of choosing a form of religion with related forms of worship, and freedom of participation (or not) in pilgrimage travel.

Therefore, it can be stated that religious beliefs (regardless of the particular form of religion) are environmentally and individually conditioned. However, the subjective point of view determines the choice of a particular form of pilgrimage tourism. An especially important factor in this matter is the vertical relationship between the human individual and the absolute. The choice of god and the nature of the involvement in religion - including the type of confessional pilgrimage - depend on the individual. Therefore, the vertical relationship with god and the consequences of the resulting pilgrimage is the proof of the subjectivity and relativity of travel dispositions characteristic of religious tourists, who are conditioned by their own axionormative decisions and their autonomously made choices. A specific form of scientific tourism and religious tourism is, for example, participation in conferences at the international and national levels. This applies in particular to those scientific and educational institutions formally, substantially, and closely associated with certain religions such as the European Association for the Study of Science and Theology (Protestant provenance); the Pontifical University of John Paul II in Krakow; or the Catholic University of Lublin (closely associated with Catholicism). Participation in conferences and academic internships, lectures, Erasmus programs, etc., very often depends on personal religious preferences and on voluntary or formal connections with a specific religion. 


\section{Scientific tourism and occupied as well as unoccupied time}

Tourism in its an autotelic form, that is, as an activity which represents a goal itself is, in its popular sense, associated with so-called free time. Therefore, it can and should occur - according to Aristotle's classic and common sense definition - before, after, or outside of work; that is, in one's spare time found away from time set aside for official duties (Aristotle 1956, Kosiewicz 2010, p. 167).

However, pairing leisure time activities with professional activity - in light of this concept of spare time and any other concept distinguishing time of work with leisure time - causes substantial dissonance for two reasons:

a) the time in which some activities take place is no longer essentially spare time,

b) the time in which some business activities are performed is no longer free time, perhaps even more significantly than in the previous example.

Regardless, however, of the type of activity which fills up one's spare time - whether workrelated to or not - this time should not be defined as free time, because it is occupied by a variety of named activities. From this perspective, time is always occupied. I claim that a human being never has spare time on his hands, as time is always occupied by some activity. From this perspective, unoccupied time does not exist. So-called spare time is always occupied with activity of some degree of intensity, and associated with human existence. Even rest, sleep, prayer or mystical ecstasy, as activities which suspend real time activities, as well as being in prison or forced to not doing anything in particular, are all confirmation of the existence of occupied time and the negation of the possibility - during the life of any organism - of unoccupied time occurring. Human subjectivity, regardless of any conscious or unconscious activity of its own, is always imbued with organic changes that occur at all time and fill up each and every individual (personal) moment to one degree or another. It is not possible for an activity to occur during unoccupied (spare time), at least in the context of human biological and cultural activities, as such time does not exist. For this reason, daily and professional activities may take place during the performance of other (planned and not planned) activities having organic, biological, cultural, or relational natures. Therefore, the type of tourism associated with the performance of professional activities can take place only when such time is occupied by other duties and specific individual needs. Also, the time should be balanced and light enough to combine tourism as an autotelic phenomenon with the obligations arising from the specific profession. From this perspective, professional tourism cannot take place during leisure time, because this time does not exist. Scientific tourism may only exist and be active during occupied time. The time is then occupied by the autotelic and instrumental (pragmatic) activity, i.e. tourism. This activity is:

a) on the one hand autotelic, because we experience, taste and delight it only for itself, as an activity itself,

b) on the other hand, instrumental, because it is a tool used to achieve in the pragmatic sense the objective of the research. The activity was undertaken due to the scientific goal.

The concept of professional tourism - including scientific tourism - is not sustainable in the context given the assumptions of the concept of spare time. Performance of any work-related activities is always related to time for work. This understanding of spare time precludes the possibility of it existing within any other autotelic activity. Therefore, scientific tourism is called pseudo-tourist peregrination (Lipiec 2008, pp. 30-31). However, when assuming the concept of the non-existence of spare time, the two components - autotelic and instrumental - can occur without causing either substantive or logical dissonance.

\section{Philosophical tourism as good and true happiness}

In the title of this text, the term protreptikos comes from one of Aristotle's earliest works, one written during his youth: Protreptikos - Exhortation to Philosophy. The work is regarded as one of the most representative pieces in philosophical literature praising the science of philosophy. It harmonizes 
- in spite of many philosophical terms or definitions used in times of the great Peripatetic - with the ancient understanding of philosophy. Protreptikos was written in the form of an open letter, dedicated to Themison, the prince of Cyprus, but intended for all people interested in the topic. Aristotle preached in praise of the philosophic life - a life fulfilled in contemplation and practice. This type of life is considered as a prerequisite for true happiness. It is also a higher form of existence in relation to other possible forms of life. Aristotle stressed that: "Wisdom is the greatest good, even if is useless in practical life" (Aristotle 1988, p. 14). He believed that philosophical thought does not necessarily bring certain tangible benefits. Philosophy is a good in itself and should be valued and desirable not for the sake of something else, but for its own (idem, p. 16). Aristotle therefore promoted the ideal of the contemplative life in spite of his interest in empirical research developed later during extensive study into inductive reasoning. He stressed the fact that only a philosophical contemplation can bring true happiness; it is the best and most enjoyable feature of the soul (pp. 10-12). Kazimierz Leśniak, summing up Aristotle's general attitude towards philosophy, shows the philosopher's conviction that

\begin{abstract}
"Wisdom is the greatest among every good and the highest goal of life; that the reason is the best part of human being, and the highest function of reason is to achieve truth; that the man is part of nature, and so the truth can be possessed by the observation of the nature; that a truly wise man will take from the nature and reality some fixed certain criteria by which one can assess what is right, noble and useful; that only the wise man knows the nature of itself and follow what is 'tied to itself'; only such man can observe the nature thoroughly and never mimic the imitations; that knowing the truth is not only good in itself, but is also useful for human life; that, finally, those who wish to achieve this goal must devote their life to philosophy." (Leśniak, 1988, pp. VII-VIII)
\end{abstract}

The observation of nature, as well as the contemplation related and dedicated to this activity, is associated with the effort needed to prepare and realize a journey. This journey is of a scientific nature, and in the case of the philosopher, it will be a philosophical peregrination. In pre-Aristotelian philosophy, and before the emancipation of the exact sciences, philosophy was considered the only science, science itself. At that time each scientific peregrination was also a philosophical pilgrimage, both expressions in fact having analogous overtones. To be exact, there is one more association that appears in relation to wandering or peregrination, and that is strolling. Strolling is a slow and not exhausting movement to a designated target of varying distances. It can be considered as a manifestation of tourism and recreation, as a physically active form of rest. Indeed, tourism is regarded, inter alia, as an active form of physical recreation, and as such is called active tourism. Therefore, the Aristotelian philosophical experience can be associated both with scientific activity and an active from of recreation. Such a supposition, it can be suggested, is based on at least three reasons. The school Aristotle founded at the Lyceum, and modeled on the Platonic Academy, became famous and is well known in the history of philosophy as a peripatetic school. For this reason, Aristotle's philosophy was called peripatetic. In one explanation of the name's origins, it is claimed that the school was located on a street called Perypatei. In a second explanation, it is assumed that in the garden where the school was located were numerous alleys (rows) called perypatei. The third and the most important interpretation, at least from the standpoint of the discussed issue, claims that philosophers led by Aristotle walked through the alleys, keenly discussing philosophical topics (Tatarkiewicz 2009). As a conclusion of the foregoing deliberation it may be stated that there are close links between science, philosophy, walking, physical recreation and this type of philosophy, which may take the form of scientific tourism, especially philosophical tourism. If one accepts that philosophical tourism is a form of scientific tourism, it is worth pointing out that in modern philosophy, there is a dispute over the nature of the relationship between philosophy and science. For example, on the grounds of scientism and logical empiricism, it was controversially argued that only the natural sciences could be considered as science, while social sciences and the humanities (including philosophy) are situated outside of science because they are mostly theoretical and speculative in nature (Kosiewicz 2010, pp. 14-20). However, with reference to Aristotle, an empiricist 
philosopher, empiricist and speculative thinker (and many other philosophers active before the seventeenth century), the differentiation indicated above is not valid. Even from the standpoint of some controversial - and already rejected - assumptions of contemporary philosophy, Aristotelian philosophy can be described as science, and thus philosophical tourism can be considered as a form of scientific tourism.

Conducted during a scientific trip, philosophical dialogue, in its broader meaning, is also an expression of one - except elenctic and maieutic - method of Socratic way of philosophical discourse, namely, the protreptic method. Its purpose is to praise and encourage (in accord with Aristotle), philosophical activity. Any form of philosophical tourism is at the same time protreptical tourism, which accompanies, inspires and reinforces the importance of philosophy thus contributing to philosophy's growth.

\section{REFERENCES}

Aristotle (1956). Etyka Nikomachejska /Nicomachean Ethis/. Warszawa: PWN.

Aristotle (1988). Zachęta do filozofii /Exhortation to Philosophy/. Warszawa: PWN.

Bertella, G. (2011). Wildlife Tourism and Natural Sciences Knowledge: Challenges and Critical Factors. Scandinavian Journal of Hospitality and Tourism, 11(1), 97-114.

Bloom, P. J. (2010). Unraveling the Ethnographic encounter: Institutionalization and scientific tourism in the Auvre of Jean Rouch. French Forum, 35(2/3), 79-94.

Cynarski, W. (2010). Między Tajpej a Pensacolą. O turystyce naukowej refleksje własne /Between Taipei and Pensacola: Personal Reflections on Scientific Tourism/. Ido. Ruch dla Kultury/Ido. Movement for Culture/, 10, 89-101.

Dupain, J., Belani, J., Likondo, C., Nzita, M., Omasombo, V. (2006). Scientific Tourism, Communal Hunting, Logging Management Plan and Participative Protected Areas: Different Approaches, the Bonobo Conservation in the Margin Lapori Wamba Landscape, Equateur Province, DRC. International Journal of Primatology, Supplement, 27, 289-290.

Ilyina L., Mieczkowski, Z. (1992). Developing Tourism in Scientific Russia. Tourism Management, 13(3), 327, 5.

Jafari, J., El-Rouby, Wahab, N. S. (1992). Scientific Tourism: Annals of Tourism Research, 19(4), 795.

James, W. (1951). Essays in Pragmatism. New York.

Kosiewicz, J. (2010). Biological Context of Physical Culture and Sport. In The Sport and Philosophy. From Methodology to Ethics. Warsaw: Wydawnictwo "BK".

Leśniak, K. (1988). Wstęp /Introduction/. In Arystoteles, Zachęta do filozofii /Exhortation to Philosophy/ (pp. VII-VIII). Warszawa: PWN.

Lipiec, J. (2008). Filozofia turystyki /The Philosophy of Tourism/. In R. Winiarski (Ed.), Turystyka w naukach humanistycznych /Tourism in the Humanities/ (pp. 13-32). Warszawa: PWN.

Piskozub, A. Podobieństwa i różnice między turystyka biznesowa a turystyka naukowa. /Similarities and Differences Between Business Tourism and Scientific Tourism//http://berda.nazwa.pl/htdocs/ ymagomundi.eu/PDF/turystyka.pdf.

Rosik, S. (1986). Sytuacjonizm etyczny a roztropność chrześcijańska /Ethical Situationism and Christian Prudence/. Poznań: Księg. Św. Wojciecha.

Sartre, J-P. (1985). Człowiek nie może uciec od odpowiedzialności /Man Cannot Escape from Responsibility/. In J. Kosiewicz (Ed.), Wspótczesna filozofia człowieka /Contemporary Philosophy of Man/. Warszawa: Wydawnictwo AWF.

Tatarkiewicz, W. (2009). Historia filozofii /History of Philosophy/. Vol 1. Warszawa: PWN.

West, P. (2008). Tourism as Science and Science as Tourism. Current Anthropology, 49(4), 597-626.

\section{AUTHOR'S ADDRESS: $\quad$ Jerzy Kosiewicz}

Department of Philosophy, Chair of the Social Sciences

Josef Pilsudski University of Physical Education in Warsaw

34 Marymoncka str., 00-968 Warsaw, Poland

Email: jerzy.kosiewicz@awf.edu.pl 